\section{Iсторія \\ медицини}

History

of medicine
ISSN: 2411-6181(on-line); ISSN: 2311-9896 (print)

Current issues of social studies and history of medicine. Joint

Ukrainian-Romanian scientific journal, 2017, №:2(14), P. 138-142

UDK 614.253:614.2.07

DOI 10.24061/2411-6181.2.2017.56

\author{
ІСТОРИЧНА ГЕНЕЗА МОРАЛЬНО-ЕТИЧНОӦ \\ РЕГЛАМЕНТАЦЇ̈ ЛІКАРСЬКОЇ ПРОФЕСІЇ \\ Марія МАНДРИК-МЕЛЬНИЧУК , \\ ВДНЗ України «Буковинський державний \\ медичний університет», Чернівці (Україна), \\ mandricescu@yahoo.com \\ Віта КОЦУР, \\ ДВНЗ «Переяслав-Хмельницький державний педагогічний університет \\ імені Григорія Сковороди», Переяслав-Хмельницький (Україна) \\ kotsurap@meta.ua
}

\title{
HISTORICAL GENESIS OF MORAL AND ETHICAL REGULATION OF MEDICAL PROFESSION
}

Mariya MANDRYK-MELNYCHUK,

Higher education institution of Ukraine «Bukovinian

State Medical University», Chernivtsi (Ukraine),

ORCID 0000000159959003

Researcher ID B-7790-2017

Vita KOTSUR,

SHEI «Pereyaslav-Khmelnytsky Hryhoriy Skovoroda

State Pedagogical University», Pereyaslav-Khmelnytsky (Ukraine),

ORCID0000-0002-6355-6714

Researcher ID B-8127-2017

\begin{abstract}
Мария Мандрик-Мельничук, Вита Коцур. Исторический генезис морально-этической регламентации профессии врача. Морально-этическое регламентирование врачебной профессии является одним из важных средств, которые обосновывают современное многоуровневое регулирование отношений, которые возникают в процессе предоставления медицинских услуг. В статье показано, что каждая эпоха сформировала свои критерии нравственности и этичности, свою совокупность норм поведения и морали, понимания предназначения, обязательств. Проанализированы исторические аспекты становления морально-этических принципов деятельности врача, формирования комплекса норм, обычаев, которые, с одной стороны, регламентируют, очерчивают профессиональные обязанности, а с другой, показывают специфичность профессиональных отношений в медицинской отрасли.

Ключевые слова: регламентация, биоэтика, права пациента, биомедицинские технологии, правовое регулирование принциипь.
\end{abstract}

Statement of the problem. Moral and ethical regulation of the medical profession is an essential component of modern medicine. Its historical origins date back to the ancient times, when fundamentals of understanding this profession, its role and authority in society were laid. Moral principles and professional culture in general express the requirements developed by human society in ancient times, the times of antiquity, Renaissance and modern times, relating to the ethical nature of a doctor and his profession. Every epoch has formed its own criteria of morality and ethics, its own set of rules of behaviour and moral, understanding of vocation and commitment. Medical ethics has become an integrative science, which absorbed the knowledge of the activities of a doctor from sociology, anthropology, ethics, philosophy, biology and so on.

Analysis of the recent research. Certain aspects of medical ethics and professional culture attracted the attention of T. Abolina, S. Viekovshynina, Yu. Vilenskyi, A. Grando, Yu. Kolisnyk-Humeniuk, N. Kovalenko,V. Kulinichenko, I. Senyuta, L.Sakharova. Considering the interdisciplinary nature of the issues of moral and ethical regulation of the medical profession and growing research interest to them by philosophers, historians, psychologists, we note that this perspective is being rather actively studied by lawyers. These arethe papers byS. Antonov, V. Sakalo, A. Vasylieva, S. Nahorna, V. Tretiakova, which bring uplegislative regulation of providing medical care by a doctor - respect for the principles of confidentiality, autonomy, privacy, their relationship with the patient, compliance of the doctor's code of ethics with current regulatory framework. But most of it is fragmentary study of this subject, require more detailed analysis of the historical background of the birth of medical ethics at different times, the factors that influenced its evolution.

The objective of the paper is to analyze the historical origins of the formation of moral and ethical principles of the medical profession, formationof a set of rules, customs, which on the one hand, regulate and outline professional duties, on the other hand, create the specific professional relationships in the medical field.

The main part of article. The constantly growing interest in the study of professional medical ethics indicates a realization of the fact that people understand, that the development of human society depends on the moral principles and norms that doctors are guided with in their professional activities. Issues of ethical regulation of the medical profession were brought up back in the days of the first practitioners, certain moral codes were developed, which were evolving according to the time challenges of each epoch.

The issue so frelations between ethics and the development of medical science, new discoveries, finding advanced treatments startedtobeconsidered back in the Babylonian codes, in Buddhist tradition, inthe concept of Aristotleaswellasin, Vedic sources. 
The Code of Laws by a king of Babylon Hammurabi $(1792-1750 \mathrm{~s}$ BC) the medical profession is regulated rather concisely and strictly. In particular, $\S \S 215-223$ formulate strict requirements for doctors' activity, the attention is accentuated on the fact that it is rated very highly in the society of those days, as evidenced by large wages for helping a patient ( $\$ 216)$. However, the doctor bore a great responsibility for people's health, especially when he did harm to his patient. For instance, $\S 218$ says that in case a doctor damages a body part of a person, their hand could be cut off. In case of quality care - «if a doctor, doing someone a heavy bronze knife cut, cures (this) man, or removesleukoma from one's eye with a bronze knife, then they will get ten sikles (a sikle is a weight unit for silver) If a doctor saved somebody's arm, leg or eye he was supposed to be paid 5 sikles» ${ }^{1}$.

An ancient Indian book «Ayurveda» describes the paternalistic relationship between doctor and patient, where the doctor is endowed with the qualities of a father who cares, protects and helps. The book citesthe words of contemporary famous healer Sushruta, «The physician should have a clean compassionateheart, calm temperament, a true nature,be characterized by the most confidence and chastity, by constant desire to do good. You can be afraid of father, mother, friends, teachers, but there should not be a sense of fear of the doctor. The latter should be kinder, more attentive to the patient than their father, mother, friends and mentor $\rangle^{2}$.

A medieval Tibetan treatise reveals the ethical principles of medical practice rather thoroughly. The source consists of four volumes and 156 chapters. There are a lot of legends about writing the treatise, one of which says that the text was first proclaimed by the Buddha himself, and then was translated into Tibetan language. The medical treatise was assigned to four groups of students - Buddhists, nonBuddhists, deities and sages. Medical ethics is described in the last chapter of the second volume called «Tantra Explanation» ${ }^{3}$.

Chapter 31 «On a doctor»gives an interesting interpretation of the medical profession, which is identified with healers. The real doctor is characterized as a curiousperson who can not be driven into a hopeless situation. Intuition is considered to be the highest type of knowledge, it is impossible to be a good doctor without it.

Interestingly, a doctor-healeris associated with «white soul» - «seeing sufferings, they decide to help, they do not differentiate between good or bad people, do not feel love or aversion to someone, they are compassionate, joyful and even-tempered ...». He has to see medication as the greatest treasure that can fulfill the desires of a patient. The medical practice is closely combined with sacrifice and prayers. "The essence of the doctor is the ability to distinguish between all kinds of signs of bad principles and their opponents. The word «doctor»itself treats the disease and it is a remedy. $\mathrm{He}$ is a hero who visits a disease with treatmentand life, he is both the father and protector.

Doctors in the treatise are divided into two categories the first are the ones that have good origins, unselfish, they do not make mistakes, take care of the affairs of others as of their own. A doctor that has no lineage (does not come from a medicinal dynasty) is compared with a fox who came tothe throne. Very high demands on the level of awareness on the methods of examination and treatment of patients are set up. It is quite important for the physician to be able to speak elegantly, to explain correctly the causes and consequences of the disease, to describe the health conditions. The doctor should not keep the confidential information about the patient, and should be honest with him and say whether he can recover and when. If the opinion on treatment do not coincide with that of the patient, the doctor has to pretend to agree, but still has to do what his wisdom and conscience suggest. The medical profession is exclusiveand unselfish, honest, the generous ones reach the country of the Gautama Buddha ${ }^{4}$.

Biographers and researchers of Hippocrates's teaching noticed that, there are many contradictory statements as to his origin and family. In particular, it has not been clearly established when he died exactly (377 or 356 BC.), and there are no sources that would confirm information about the ancestry of Hippocrates (on his father's side he was a descendant of the Greek god of medicine Asclepius and on the mother's side he descended from the god Hercules. Referring to the works of a famous Roman physician, a Greek by birth, representative of the methodical school,founded by Asclepiades, Soranus of Ephesus Hippocrates'sbiography and genealogy researcher, it is believed that Hippocrates'sfather was the physician Heraclitus, and his mother was the midwife Fenareta ${ }^{5}$. He had two sons - Fesal and Drakont, and their children were all named Hippocrates after their grandfather.He also had a daughter, whose husband inherited the developments by the physician Galen.

Soranus of Ephesus says that in addition to medical science Hippocrates studied the philosophy from Democritus and Gorgias (a sophist). To improve his knowledge and experience, he also traveled to various countries and studied theirmedical practice.

His name is associated with a series of medical treatises, which are united under a provisional name «Hippocratic Corpus»According to some researchers, they could be written or in different periods of the prominent doctor's life, or their authors are a whole group of his relatives. Immediately he was recognized as the author of 18 medical works, including «The Oath», which laid the foundations of the moral and ethical aspects of a doctor. It was written in the 5th centuryB.C. in the Ionian dialect of the ancient Greek language.

The text has been translated and even modifiedmany times; some of its points have lost its original meaning. As a modern scholar I. Busel notes, for a long time the Oath was used with significant amendments in the Christian world: mentioning Greek gods was replaced by the Christian God. Historical origins to the formation of medical ethics reach the theoretical heritage of Aristotle. Aristotle's father,

\footnotetext{
${ }^{1}$ Istoriya Drevneho Vostoka. Tekstyi dokumenty [History of the Ancient East. The texts and documents: Tutorial], Uchebnoe posobie, Pod red. V.Y. Kuzishchina, Moskva, Vysshaya shkola, 2002, P. 183-184.

${ }^{2}$ Sharma P.V., History of Medicine in India (from Antiquity to 1000 a.d.), New Delhi, Indian National Science Academy, 1992,527 p.

${ }^{3}$ «Chzhud-Shy»- pamyatnik srednevekovoy tibetskoy kul'tury [«Chzhud-Shi» - a monument to medieval Tibetan culture], Novosibirsk, Nauka, 1988, 349 p.

${ }^{4}$ Ibid.

${ }^{5}$ Kitsera N.I., Kitsera R.O. "Soran Efes'kiy - korifey akusherstva i hinekolohiyi” [Soranus of Ephesus - coryphaeus of Obstetrics and Gynecology], Zhinochyy likar, 2012, N. 5, P. 65.
} 
Nicomachus, was a physician from Asclepiades's family, where the medical profession was hereditary. Two branches of the family began with the descendants of Asclepius doctors Machaon and Podaleirios. It was from one of them that Hippocratesdescended ${ }^{6}$. The fact that Nicomachus was a court physician of Amyntas II of Macedon - a Macedonian king,Hippocrates's sonThessalus treated Archelaus and his grandson - the wife of Alexander I of Macedon, allows assuming that Aristotle's father wanted him to become a doctor too. The boy was orphaned pretty early, but that did not prevent him from self-education and from going purposefully to his goal. Training in the Platonic Academyfor almost twenty years made it possible not only to get a huge arsenal of knowledge, but also to develop a unique style of thinking. This allowed the thinker to penetrate deeply into the essence of phenomena, including those relating to ethical regulation of human life and the medical profession in particular.

Aristotle became the author of the theory of ethics, laying the basis for the formation of bioethical knowledge in the future. This is a series of virtues that the philosopher formulated and on which the medical profession is still based. In particular, the «Nicomachean Ethics» states that the first of them was courage (andreia) It is one of the most important virtues for a doctor, because it allows him to decide on the life of another person. «Courage is a possession ofthe midpoint between fear (Gr. phobos) and courage (Gr. tharrhe) ...» ${ }^{7}$. The second one is a sound sense (Greek. phronesis) that is, an ability to make correct and deliberate decisions that contribute to improving quality of life. The point is that the doctor has to take immediate, but always well-consideredmeasures, to understand whatis the best and the most effective, and what will promote the person's recovering in general. Otherwise, it can lead to disastrous consequences, even death of the patient ${ }^{8}$. The third virtue, without which effective communication between patient and doctor isimpossible, is friendliness (Gr.philia) ${ }^{9}$. In fact, the doctor has to become a friend to the patient, as the level of trust will directly depend on this, and so will the result of the treatment. The examination, drug and procedure administration involve close and subtle interaction between patient and doctor. Another virtue that a real doctor needstopossessis self-control (praios), i.e. the ability to restrain their emotions, not to fall into a state of anger and despair, to keep their balance in difficult situations ${ }^{10}$. Consideringa special status of the doctor, as they can affect the fate of another person, give life «to give another breath», they aresupposed to accept patients as equals. This virtue was called majesty by Aristotle. The thinker understands it as generosity and greatness of soul, honesty, nobleness, modesty, moderatenessof pleasures. The doctor's profession is incompatible with malice, envy, vainglory, arrogance and vanity. Each virtueisregarded bythephilosopheras the golden mean between lack and excess of certain traits or behavior «that moral virtue means possession of the midpoint and in what sense, and that this possessionofthe midpoint between two vices, one of which is in excess, and the other - in lack, and that virtue means achieving midpoint both inpassions and in actions» ${ }^{11}$.

Aristotle's medical views were formed under the influence of two other great Greeks - Galen and Hippocrates ${ }^{12}$. Their concepts were «adapted»by the Church too. Aristotle built his views on the contemplation of nature, which was a determining factor in understanding problems related to the interpretation of ethical issues and problems dealingwith human health.

During the nineteenth and twentieth centuries there was a significant correction of medical ethics formulated by Hippocrates. The authors point out that it was caused by spreading the theory of social Darwinism, which imposed a misrepresented understanding of the role of medical care. The doctor was said to be able to use their activities to affect the natural struggle for existence. Such approaches have even generated, on the verge of the nineteenth and twentieth centuries,movement of «eugenics», which fought for the qualitative improvement of human population ${ }^{13}$. In 19301940s. a program of forced sterilization of people with serious mental disorders or physical disabilities, of antisocial personalities was being actively implemented. At the same time, the program of euthanasia wasadvocated;experiments on human beings without their consent were encouraged.

Considerable changes in the understanding of medical ethics took place during the Soviet period. Medicine in the Soviet Union was significantly different from that in the West, as it was influenced by ideology, and therefore the text of the oath stated: «to keep and promote the noble traditions of domestic medicine in all my actions guided by the principles of communist morality ...» ${ }^{14}$. The Soviet medicine evolved, to some extent, in the vacuummedium, divorced from the processes that took place in the western world. For example, in European countries and in the USA many of the Hippocratic Oath statements have become the subject of criticism among doctors, lawyers, philosophers. Medical ethics did not meet the requirements of time, the changes that had occurred in the relationship between doctor and patient and the newest biomedical technologies. The problem of subjectivity of a doctor'sdecisions regarding the choice of a methodology of treatment was especially critisezed.

In 1960s-1970sa new direction of interdisciplinary philosophical, theological, jurisprudential, medical research - bioethics appears asbioethics. One of the founders of bioethics was an American philosopher and Harvard professor Daniel Callahan, who took the ethical concept of Aristotle as the basis of bioethical knowledge formation. In 1969 together with a psychiatrist William Gaelinhe cofounded the Institute for Social Ethics (The Hastings Center)

\footnotetext{
${ }^{6}$ Arystotel'.O chastiakh zhyvotnykh [On the parts of animals], Perev. V. P. Karpova, Moskva, 1937, P. 12-13.

${ }^{7}$ Arystotel'. Nykomakhova etika [Nicomachean Ethics],book II (B), Chapter VII, URL: http://www.e-reading.club/chapter.php/71882/2/ Aristotel\%27_-_Nikomahova_etika.html

${ }^{8}$ Ibid.

${ }^{9}$ Ibid.

${ }^{10}$ Ibid.

${ }^{11}$ Ibid.

${ }^{12}$ Hlyayzer H. O myshlenii v meditsyne [About thinking in medicine], Moskva, Medytsyna,1969, $268 \mathrm{p}$

${ }^{13}$ Chystenko H. N., Dronyna A. M. "Meditsynskaya etika, ot etiki Hippokrata - do sovremennykh problem bioetiki" [Medical Ethics: from Ethics of Hippocrates - to contemporary bioethical issues], Mir meditsyny, Minsk, 2013, N. 10, P. 2-4.

${ }^{14}$ Busel I. «Klyatva Hippokrata» [Hippocratic Oath], Otkrytiya i hipotezy, 2012, N. 6, P. 23.
} 
- a leading research institution in the field of bioethics. Later on, he became the President, Director of International Programs of the Center. Outlining the main purpose of bioethical knowledge, D. Callahan argued that «understanding the emergence of bioethics will help to embrace the panorama and complexity in this area ... $\rangle^{15}$.

It was the 1960s that he proposed to consider to be the starting point of the new direction of research, although bioethics historical origins date back to the times of ancient Egypt, India, China and Antiquity era.

For the first time this term, in relation to theoretical developments in the field of human moral and ethical regulation of relationship between doctor and patient, adopting the fundamental principles of preservation of life, was used in 1970 by an American scientist Van Ranselerom Potter. It is the foundation of the Hastings Center and John. F. Kennedy Institute of Ethics, Georgetown University that is considered the origin of bioethics as a unique combination of biomedical sciences, public health practice with moral and ethical heritage of eastern, ancient and medieval philosophies.

Famous American researchers of ethical aspects of medicine J. Childress and T. Beauchampin 1989 formulated the basic principles of bioethics, doctors have to follow ${ }^{16}$. They meanthe autonomy, «do not harm», justice and mercy. The practical implementation of these principles involves adherence to certain rules - privacy, confidentiality, reliability, «informed consent». The borders of a person's privacy, their right to choose and decide according to their own system of moral values are defined. Therefore, the undeniable competence of the doctor is being questionned. The patient gives voluntaryconsent to intervene in their lives, to examine them, to diagnose. Besides, the physician hasto minimize thepatient'sworries, not to press on the patientpsychologically, not to make them suffer.

«Informed consent» was the subject of separate studies in history and philosophy of medicine. For instance, analyzing the origins of the use of the term, V.A. Sakalo says that the term «consent»meaning the relationship between doctor and patient was first referred to in legal documents in the eighteenth century. In the early twentieth century this rule becomes legal as «informed consent to medical intervention» and gets more specific interpretation in 1914 thanks to the US Supreme Court Judge B. Cardoso. It meant that every adult person with sound mind has a right to know what the doctor is going to do to them and what the possible negative consequences might follow. If thedoctordoessomethingwithout thepatient's consent, theywill be charged with assaulting a person and be punished correspondingly ${ }^{17}$.

In the early 1990s this principle became a law in the Ukrainian medicine too. In 1992 the Ukrainian Parliament adopted the Law of Ukraine «Fundamentals of the legislation of Ukraine about health care», according to which receiving a conscious «informed consent»is compulsory before to diagnose or use a particular method of treatment. The person has to receive accurate information about their condition, alternative treatments,possibleconsequences in the event of their re- fusal.

If we return to the principles of bioethics, there are two more, that are closely related to each other, but they mean something different. The principle of mercy or «do good» can be interpreted as the doctor's obligation to seek the best way of medical treatment using their experience and emotional sphere. «Do not harm» includes not only direct actions, but also those that could bring pain and suffering, psychological discomfort, even cause death. Not only does it include professional qualities and medical skills, but also their moral principles and inner world. Equally important is keeping the principle of justice, which means obligatory meeting human needs in health care, it is important,in particular,in terms of the increasing commercialization of medicine.

Let us refer to the developments of a famous American expert on bioethics, director of the John. F. Kennedy Institute of Ethics, Georgetown University (1989-1996) Robert Veatch -one of the leading researchers in the field of medical ethics and philosophy of medicine in the world. The greatest influence on the formation of his scientific views had conceptsbyI. Kant, T. Kuhn and D. Hume.His particular attention was paid to the role of value judgments in making medical decisions. The scientist denied stereotypes, that only doctors have a monopoly to produce ethical principles of operation of their profession. R. Veatchbecame one of the most powerful critics of the Hippocratic paternalistic theory in medical ethics. It is about the relationship between doctor and patient, which resembles somewhat dependent relationship between the priest (pastor) and parishioner, or, as according to Confucius, the governor of the state plays the role of a father, guardian, the same idea is that of Hippocrates - the doctor should exercise tolerance, love and attention to the patient's problems as well as compassion.However, R. Veatch considers it to be a serious problem, because the doctor and the patient's relations are unequalwhen a sick person should strictly abide by instructions of their doctor, who has a significant (insufficient) arsenal of necessary knowledge and experience. R. Veatch was the author of the contract theory of medical ethics which envisages equality and partnership between doctor and patient in decisions regarding methods of treatment, patient's receiving full information about their health, the right to refuse further treatment if the patient does not want to continue it.According to the scientist, the fact that life can get in the hands of amateurswhich may have irreversible consequences, is unacceptable, as their choice as to what may be appropriate for the patient (drugs, methods, surgery) might be wrong. On the other hand, the development of biomedical technology brings up theneed of legal and moral delineation of boundaries that that can not be overstepped by scientific experiments.

During the 1980s-1990s. there was also a legal regulation of ethical aspects of the doctor's activity. The first steps in the legislative consolidation of bioethical norms were established back after World War II in the Geneva Declaration (1948), which reflected the position of the Nuremberg Code regarding the prohibition of experiments on human beings, the International Code of

\footnotetext{
${ }^{15}$ Daniel Callahan, Bioethics, Encyclopedia of bioethics, Reich W.Th. Editor-in-chief. N. Y., 1995, VI., P. 248.

${ }^{16}$ Vyekovshynina S.V., Kulinichenko V.L., Kovalenko N.V. "Suchasna medychna etyka: vid Hippokrata do bioetyky" [Contemporary medical ethics from Hippocrates to bioethics], Ukrayins'kyy medychnyy chasopys, 2003, N. 5 (37), P. 93-96.

${ }^{17}$ Sakalo V.O. "Informovana zhoda na medychne vtruchannya: bioetychnyy aspect" [Informed consent to medical intervention: bioethical aspect], Forum prava, 2012, № 2, P. 609.
} 
laid down in the Lisbon Declaration, adopted in 1981 by $34^{\text {th }}$ World Medical Assembly, which defined clearly the rights of patients. The principle of medical services acceaccessibility has been fixed by relevantVienna Regulations adopted by the $40^{\text {th }}$ World Medical Assembly in 1988. In 1990a resolution on human rights was adopted in California. In addition, considering the growing relevance of bioetic problems and the need to develop common standards and principles of professional doctorstheInternational Bioethics Committee was created in 1993as an advisory body of $\mathrm{UNESCO}^{18}$.

Another important step in the specification of the patient's rights was the Amsterdam Declaration adopted at the European conference onpatients' rights in 1994.In 2005 the «Universal Declaration on Bioethics and Human Rights» was adopted. Although the documentsare not binding, the fact itself that the countries signed it, means accepting the principles embodied in the declaration. By the way, thenumberofprincipesinit increasedgreatly: from basic 4 to 15 principles: human dignity (Art. 3), human rights (Art. 3), the good and the harm (art. 4), independence and individual responsibility (Art. 5) consent (Art. 6), recognition of human vulnerability and personal immunity (art. 8), equality, justice and equalrights (Art. 10), solidarity and cooperation (art. 13), protection of future generations (Art. 16) ${ }^{19}$.

Among the main problems, the present-day bioethics deals with, are the patient's right to life (use of new reproductive technologies and ethical aspects of organ transplantation, genetic engineering, experimentation on humans, maintaining medical confidentiality and possible fatal consequences), the right to death (euthanasia), etc.

Thus, the current moral and ethical regulation of the medical profession, the relationship between doctor and patient, passed a long way of evolution. Many of the period of the ancient world, antiquity, the Middle Ages suffered criticism, some have become irrelevant as, for example, the principle of paternalism. Modern medical ethics has undergone major changes. It not only identifies certain moral limits of medical practice, but more pragmatic forms the ethical and legal framework for prevention of Medicine in inhumane purposes.

Мандрик-Мельничук Марія, Коцур Віта. Історична генеза морально-етичної регламентації лікарської профеciї. Морально-етичне регламентування лікарської професії $\epsilon$ одним 3 важливих засобів, що обгрунтовують сучасне багаторівневе регулювання відносин, що виникають в процесі надання медичних послуг. Історичні витоки виникнення становлен- ня лікарської етики сягають у далекі стародавні часи, коли були закладені основи розуміння цієї професії, ії важливості та авторитетності в суспільстві. У статті доведено, що моральні принципи та загалом професійна культура виражають напрацьовані людською спільнотою в стародавні часи, періоди античності, ренесансу та новітні часи вимоги, що стосуються етичної сутності лікаря та його діяльності. Показано, що кожна епоха сформувала свої критерії моральності та етичності, сукупність норм поведінки і моралі, розуміння призначення, зобов'язань.

Проаналізовано історичні аспекти становлення моральноетичних принципів діяльності лікаря, формування сукупності норм, звичаїв, які, з одного боку, регламентують, окреслюють професійні обов' язки, а з іншого, творять специфіку професійних стосунків у медичній галузі.

Ключові слова: регламентація, біоетика, права пацієнта, біомедичні технології, правове регулювання, принципи.

Мандрик-Мельничук Марія - доктор історичних наук, доиент кафедри сочіальної медичини та організачії охорони здоров'я Буковинського державного медичного університету. Коло наукових інтересів: історія України ХХ століття, етнополітика, ідеологія, історична та соиіальна пам'ять. Автор понад 150 наукових праџь, у тому числі 4 монографій, 6 науково-методичних посібників.

Mandrik-Melnichuk Maria - Doctor of Historical Sciences, Associate Professor of the Department of Social Medicine and Health organization of Higher Educational Institution "Bukovina State Medical University". Research interests: history of Ukraine of the twentieth century, ethnic politics, ideology, historical and social memory. Author of over 150 scientific works, including 4 monographs, 6 scientific-methodical manuals.

Коцур Віта - кандидат історичних наук, викладач кафедри історії та культури Украӥни ДВНЗ «ПереяславХмельницький державний педагогічний університет імені Григорія Сковороди». Коло наукових інтересів: сучасна українська історіографія, історія Украӥни козаиької доби, історія науки та техніки, краєзнавство. Автор 103 наукових, науково-популярних та навчально-методичнихпрачь.

Kotsur Vita - candidate of historical Sciences, lecturer of the Department of history and culture of Ukraine "PereyaslavKhmelnitsky state pedagogical University named after Grigory Skovoroda". Research interests: contemporary Ukrainian historiography, history of Ukraine the Cossack era, the history of science and technology, regional studies. The author of 103 scientific, scientific-popular and educational-metatechnical

Received: 18. 01. 2017

Advance Access Publisched: April, 2017

(C) M. Mandryk-Melnychuk, V. Kotsur, 2017

\footnotetext{
${ }^{18}$ Khenk ten Khave, "Deyatel'nost' UNESKO v oblasti byoetiki” [Activities of UNESCO in the field of bioethics], Kazanskiy meditsynskiy zhurnal, 2008, N. 4, P. 377-383.

${ }^{19}$ The UNESCO Universal Declaration on Bioethics and Human Rights: background, principles and application, edited by Henk A.M.J. ten Have and Michele S. Jean, Adopted by the UNESCO General Conference resolution on the report of the Commission at the $18^{\text {th }}$ plenary meeting on October 19, 2005, Paris, 2009, 370 p.
} 